\title{
Constitutionality Of Simultaneous Regional Head Elections Through E-Voting According To The Constitutional Court Decision
}

\author{
Moh. Saleh ${ }^{1}$, Sukardi $^{2}$, Mohammad Ferdian Rizal ${ }^{3}$ \\ \{saleh.nwa@gmail.com ${ }^{1}$, sukardi_ws@yahoo.co.id ${ }^{2}$, m.ferdian.rizal@gmail.com ${ }^{3}$ \} \\ Doctoral Student at Faculty of Law Universitas Airlangga ${ }^{1}$, Lecturer of Faculty of Law Universitas \\ Airlangga $^{2}$, Student of Master of Law at Faculty of Law Narotama University, Surabaya, Indonesia ${ }^{3}$
}

\begin{abstract}
This paper aims to explain the constitutionality of simultaneous regional head elections through e-voting according to the Indonesian constitutional court decision. The method of this study is conducted with literature, statute, and court decision review. The results found that the e-voting can be used in simultaneous regional head elections with provision that it does not violate the principle of direct, general, free, secret, honest, and fair in electoral providence of the regional head according to the Constitutional Court Decision Case Number 147/PUU-VII/2009. This paper concludes that the simultaneous regional head through e-voting is constitutional. The use of E-Voting can prevent various forms of violations in electoral providence of the regional head.
\end{abstract}

Keywords: Constitutional Court Decision, Regional Head Election, E-Voting

\section{Introduction}

Regional Head Election is an important instrument for a democratic country where people are the holders of sovereignity can directly elect a regional head [1]. Democratic system put every citizen in a free and equal place as mentioned in Jürgen Habermas' Conception that "a self-organising communiti of free and equal citizens, coordinating their collective affairs through their common reason"[2]. Therefore, all citizens have the same political rights to vote and rights to be candidate in a Regional Head Election [3].

At the time of enactment of Law Number 32 of 2004 concerning Regional Government, Regional Head Election in all regions in Indonesia were not held simultaneously in accordance with the end of the term of office of regional head and deputy regional head. However, since the enactment of Law Number 1 of 2015 concerning the Determination of Government Regulation in Lieu of Law Number 1 of 2014 on the Election of Governors, Regents, and Mayors Becoming an Act as last amended by Law Number 10 of 2016 concerning the Second Amendment of Law Number 1 of 2015 concerning the Determination of Government Regulation in Lieu of Law Number 1 of 2014 on the Election of Governors, Regents, and Mayors Becoming an Act, Regional Head Election is held simultaneously. The implementation of a simultaneous Regional Head Election is carried out in 5 (five) waves as in the following table:

Table 1. The Implementation of a Simultaneous Regional Head Election in Indonesia 


\begin{tabular}{lll}
\hline Waves & $\begin{array}{c}\text { Date of the } \\
\text { Simultaneous Regional } \\
\text { Head Election }\end{array}$ & Number of Provinces and Districts/Cities \\
\hline I & December $9^{\text {th }}, 2015$ & 9 province, 244 districts, dan 36 cities \\
II & February $15^{\text {th }}, 2017$ & 7 province, 76 districts, dan 18 cities \\
III & June $27^{\text {th }}, 2018$ & 17 province, 115 districts, dan 39 cities \\
IV & September 2020 & 9 province, 244 districts, dan 36 cities \\
V & November 2024 & 34 province, 415 districts, dan 93 cities \\
\hline
\end{tabular}

Source: Processed from Law Number 10 of 2016.

Based on the data from Election Organizer Ethics Council (DKPP) on the Simultaneous Regional Head Election in 2015 stated that there were 109 (a hundred and nine) cases of violations of ethic codes examined by the Election Organizer Ethics Council with a total number of 456 (four hundred fifty six) people [4]. For violations in the form of criminal acts in the Simultaneous Regional Head Election in 2015 there were 29 (twenty nine) cases of Regional Head Election criminal acts handled by the Directorate of General Crimes Criminal Investigation Department of Indonesian National Police [5]. For disputes in the Simultaneous Regional Head Election in 2015 there were 177 (a hundred seventy seven) cases [6]. For disputes in the Simultaneous Regional Head Election in 2015 in the form of disputes over the result of the vote in the Regional Head Election there were 148 (a hundred forty eight) cases submitted to the Constitutional Court [7].

The large number of violations and disputes in the Simultaneous Regional Head Election in 2015 became a parameter of Indonesia's poor quality of democracy. To improve the quality of democracy in Indonesia, it becomes a necessity in the simultaneous Regional Head Election not to be carried out conventionally, but rather by using information and technology or what is called Electronic Voting (E-Voting). Regional Head Election that used E-Voting can resolve the violations and disputes that emerged from the simultaneous Regional Head Election in Indonesia [8].

\section{The Application of E-Voting in Several Countries}

According to the Agency for the Assessment and Application of Technology, a number of reasons for developed and developing countries to apply E-Voting are [9]:

a. No need to print paper ballots, so it supports green technology program;

b. Voting is easily done by touching the image on the touch screen depicting the ballots;

c. The counting process will be faster, more precise and accurate. At the time of the collection, the closing process is done and the results can be obtained directly;

d. Sending the ballots directly to the data center using the existing communication infrastructure;

e. Vote tabulation can be done automatically through a tabulation application that displays the results from each machine at each polling station;

f. Web-based viewing results which guarantee public transparency and speed in accessing the election results;

g. Generate an audit trail either digitally or electronically as well as an archive system in the form of audit paper or the voter's vote receipt;

h. The audit process of the audit box and comparing it with the electronic ballot box is the proses proposed in the E-Voting process; 
i. Time efficiency brings a tremendous impact that can be calculated in cost efficiency; and

j. Do not have to use the State Electricity Company as an electricity source because it can be operated using a battery such as car battery.

Many advantages in the application of E-Voting have become the choice of many countries in the world. Some countries that have applied the E-Voting systems are [10]:

1. Australia

The use of E-Voting was first known as CyberVote by Midac (Microprocessor Intelligent Data Acquisition and Control) in 1995 for a poll (petition) regarding the French nuclear test in the Pacific. On October 2001, E-Voting was used for the first time in the Australian's parliamentary election.

2. Brazil

In 1996, a trial was conducted in the State of Santa Catarina. Since 2000, all elections in Brazil have done in E-Voting.

3. Estonia

E-Voting in Estonia began in October 2005 in local elections. Estonia became the first country to hold elections through the Internet and was declared a succes by Estonian election officials. Estonia has been named as a country that organizes E-Voting through the Internet nationally.

4. France

On January 2007, Union for a Popular Movement (UMP) Party held a Presidential Election using remote E-Voting and also through 750 polling stations that provide touch screens.

5. India

E-Voting was first introduced in 1982 and was used during the trial of the election of the Bort Parur Assembly in Kerala State. However, the Indian Supreme Court cancel the election result because it was not in accordance with the law in force there. Therefore, an amandment to the Law of the People's Representatives was then carried out to certify the elections that held through the Electronic Voting Machine (EVMs). In 2003, all elections in the state had use EVMs and were also used in national elecctions to elect members of the Indian parliament in 2004 and 2009.

6. Italy

On the $9^{\text {th }}$ and $10^{\text {th }}$ of April 2006, the city of Cremona have used a voting machine in national election.

7. Philippines

On May 2010, the Philippine government has planned to hold elections electronically for the first time using the optical scan voting system. On May 10 $0^{\text {th }}, 2010$, the Filipinos have chosen the President using the E-Vote for the first time.

8. The United States of America

The United States of America have applied the E-Voting in the 2004 Presidential Election, but there were failures at some polling stations. So, the technology was perfected and known as the Verifiable Paper Andit Trial (VVPAT).

\section{E-Voting Constitutionality According to Indonesian Constitusional Court Decision}

E-Voting is an election system where data is recorded, stored, and processed in the form of digital information. According to Centinkaya and Centinkaya, "E-Voting refers to the use of 
computers or computerised voting equipment to cast ballots in an election."'[11]. So, E-Voting is basically the application of an electronic (digital) voting starting from the registration process, the voting, the counting, and sending the results of the vote.

Current technological development have been able to guarantee the validity and security of both business and political interests. Therfore, the E-Voting system is very effective to ensure the democratic elections and in accordance with the principles of the general election [12]. As said by Dwi Handoko that E-Voting can be securely guaranteed in electronic transactions, it can be proven that there are electronic transactions in the voters' voting, and the authenticity of the voters' participants can be verified using electronic IDs, fingerprints, and can be ensured of its unique singularity [13].

To this day, there are no provinces or districts/cities in Indonesia that have applied E-Voting in Regional Head Election. Nonetheless, in 2009, E-Voting was applied in 54 (forty five) hamlet heads and village head election in Mendoyo Dangin Tukad Village in Jembrana District. E-Voting was held as a pilot project for the application of the E-Voting for national election [14].

The Pilot Project in the hamlet heads and village head election in Jembrana District in Bali should have been applied in the simultaneous Regional Head Election in Indonesia. According to the Constitutional Court as the quardian of the constitution and the interpreter of the constitution ${ }^{15}$ has decided in Case Number 147/PUU-VII/2009 that the E-Voting system is in no way contrary to the 1945 of the Constitution of the Republic of Indonesia or any laws that concern about Regional Head Election. The Constitutional Court gives consideration in their decision that the Regional Head Election was done by checking the candidate must be broadly interpreted including the E-Voting system as long as it does not violate the principles of a direct, general, free, confidential, honest and fair election. In point 3.14 paragraph 3 and 4, the Constitutional Court states:

That voting was done by checking one of the candidates as long as it does not conflict with the principles of a direct, general, free, confidential, honest and fair election, it does not decrease its validity as it is still within reasonable limits. Likewise, other methods such as E-Voting is constitutional as long as it does not violate the principles of a direct, general, free, confidential, honest and fair election;

Nevertheless, the use of E-Voting methods must be based on objective considerations, namely the readiness of the election officials and the people, sources of funding and technology, and other related parties that need to be prepared carefully. Based on the principle of benefit, the Court considers Article 88 Law number 32 of 2004 is constitutional as long as it means that it can use the E-Voting method with cumulative terms as follows:

1. Does not violate the principles of a direct, general, free, confidential, honest and fair selection;

2. Regions that apply the E-Voting method are ready in terms of technology, financial, human resources, and software, the readiness of the people in the concerned area, and other requirements needed;

Based on the basis of constitutionality in the Regional Head Election using E-Voting, then the simultaneous Regional Head Election in Indonesia should have applied E-Voting. The application of E-Voting in this simultaneous Regional Head Election must be adjusted to the law development in legislations and Constitutional Court decision. 


\section{Conclusion}

According to the Constitutional Court in Case Number 147/PUU-VII/2009, the Regional Head Election through E-Voting is constitutional, as long as it does not violate the principle of a direct, general, free, confidential, honest and fair election. The Constitutional Court uses an extensive interpretation that E-Voting is an extension of the meaning of checking one of the candidates in the ballots. However, provincial and districts/city that will apply E-Voting in the simultaneous Regional Head Election must be prepared in terms of technology, financial, human resources, as well as the software needed in the E-Voting system, the readiness of the people in the concerned area, and other requirements needed.

\section{References}

[1] Muhjad, M. Hadin: Sistem Pemilihan Kepala Daerah Secara Demokratis. Disertasi pada Program Pascasarjana Universitas Airlangga, Surabaya (2007)

[2] Schneider, Cornelia: The Constitutional Protection of Rights in Dworkin's and Harbermas' Theories of Democracy. Vol. 7, UCL Jurisprudence Review (2000)

[3] Rahayu, Susi Dian: Pilkada dan Penguatan Demokrasi di Aras Lokal untuk Mencapai Good Govermance. Vol. 1, No. 3 Oktober, Jurnal Etika \& Pemilu (2015)

[4] Dewan Kehormatan Penyelenggara Pemilu Republik Indonesia: Outlook 2016, Refleksi \& Pproyeksi. Dewan Kehormatan Penyelenggara Pemilu, Jakarta (2016)

[5] Dewan Kehormatan Penyelenggara Pemilu Republik Indonesia: Potret Pemilukada Serentak 2015. Dewan Kehormatan Penyelenggara Pemilu, Jakarta (2015)

[6] Komisi Pemilihan Umum Republik Indonesia: Laporan Tahunan Komisi Pemilihan Umum 2015, Jakarta (2016).

[7] Komisi Pemilihan Umum: Keadilan di sengketa Pilkada. Edisi VII, Januari-Februari, Suara Komisi Pemilihan Umum (2016)

[8] Riera, A., \& Brown, P.: Bringing Confidence to Electronic Voting,. 1 (1), 14-21. Electronic Journal of e-Government (2003) and de Vuyst, B., \& Fairchild, A.: Experimenting with Electronic Voting Registration, the Case of Belgium. The Electronic Journal of eGovernment , 2 (2), 87-90, 2005

[9] Badan Pengkajian dan Penerapan Teknologi: Alih Teknologi Metode Pemilihan Kepala Desa Menggunakan E-Voting dan E-KTP di Kabupaten Jembrana, Desa Mendoyo Dangin Tukad, 29 Juli 2001

[10] Rokhman, Ali: Prospek dan Tantangan Penerapan E-Voting di Indonesia. Seminar Nasional Peran Negara dan Masyarakat dalam Pembangunan Demokrasi dan Masyarakat Madani di Indonesia. Universitas Terbuka, Jakarta, 7 Juli 2011

[11]Centinkaya, O., \& Cetinkaya, D.: Verification and Validation Issues in Electronic Voting, 5 (2), 117-126, The Electronic Journal of e-Government (2007)

[12] Gritzalis, D.: Secure Electronic Voting, New Trends New Threats. Dept. of Informatics Athens University of Economics \& Business and Data Protection Commission of Greece, Athens (2002)

[13]Indonesian Constitutional Court Decision Case Number 147/PUU-VII/2009 concerning Reviewing of Law Number 32 of 2004 on Local Government

[14] Anistiawati, Made Leita: Implementasi Kebijakan Penerapan Elektronik Voting (EVoting) Dalam Pemilihan Kepala Desa (Studi Kasus: Pemilihan Kepala Desa di Desa Mendoyo Dangin Tukad, Kecamatan Mendoyo Kabupaten Jembrana). Program Studi 
Administrasi Negara Fakultas Ilmu Sosial dan Ilmu Politik Universitas Udayana, Denpasar (2011)

[15] Asshiddiqie, Jimly: Konstitusi \& Konstitusionalisme di Indonesia. Sinar Grafika, Jakarta (2010). 